\title{
In vitro Nutritional Evaluation and Digestion Kinetics of Concentrates Containing Varying Levels of Moringa oleifera Leaf Meal Supplementation as Protein Source for Goats
}

\author{
Pravin Sharma, J.S. Lamba*, Jasmine Kaur and R.S. Grewal
}

Department of Animal Nutrition, College of Veterinary Science, Guru Angad Dev Veterinary and Animal Science University, Ludhiana, India

*Corresponding author

\begin{tabular}{|l|}
\hline Ke y w or d s \\
$\begin{array}{l}\text { In vitro gas } \\
\text { production, } \\
\text { Moringa oleifera }\end{array}$ \\
\hline Article Info \\
\hline $\begin{array}{l}\text { Accepted: } \\
26 \text { March } 2020 \\
\text { Available Online: } \\
\text { 10 April 2020 }\end{array}$ \\
\hline \hline
\end{tabular}

\section{A B S T R A C T}

The present study was undertaken to study the effect of varying levels of Moringa oleifera leaf meal (MOLM) supplementation on in vitro utilization of concentrate mixtures replacing total crude protein of soybean@10,20,30,40 and 50\%.The net gas production was significantly increased as the moringa supplementation level increased in the concentrate ration. It was significantly higher in $30 \%$ moringa based concentrate and significantly lowest in control concentrate. The partition factor (PF) was significantly lowest in 30\% moringa concentrate (3.71) and significantly higher in $10 \%$ moringa containing concentrate mixture (4.26). The OMD was significantly higher in $30 \%$ moringa based ration and lowest in control ration but it was statistically comparable in moringa supplemented concentrate rations. The NDFD was significantly higher in $30 \%$ moringa concentrate ration but statistically comparable in moringa leaf meal supplemented concentrate rations. The MMP and EMMP was significantly higher in $10 \%$. However, it was statistically comparable in all moringa leaf meal supplemented concentrate rations. The true digestibility was significantly higher in $30 \%$ moringa supplemented and it was significantly lower in control ration. The ME value was significantly lower in control concentrate and statistically higher in 30\% moringa supplemented ration followed by $40 \%$ moringa based ration. It can be concluded that Moringa oleifera leaf meal can replace up to30 percent protein of soybean meal without any adverse effect.

\section{Introduction}

Globally, agriculture plays a key role in improving livelihood, especially in rural communities. Livestock is the mainstay of the agricultural community. It provides $50 \%$ of the value of agricultural output globally and one third in developing countries. During the past 3 decades, rapid increase and development in the livestock sector have led to the livestock revolution. The livestock sector in India alone contributes nearly $25.6 \%$ of the value of output at current prices of the total value of output in Agriculture, Fishing \& Forestry sector. The overall contribution of the Livestock Sector in total GDP is nearly $4.11 \%$ at current prices in 2012-13. 
At present, the country faces a net deficit of $61.1 \%$ green fodder, $21.9 \%$ dry crop residues and 64\% feeds. The deficit of Supply and demand scenario of forage and roughage at present is 696 (63.50) and dry 143 (23.56) million tonnes. The situation is further aggravated due to the increasing growth of livestock particularly that of genetically upgraded animals.

Livestock scientists are eager to explore and investigate good-quality fodders that can boost milk and meat production in an organic and economical way. Moringa oleifera is one of those plants that has been neglected for several years, but now is being investigated for its fast growth, higher nutritional attributes, and utilization as a livestock fodder crop. The Moringa oleifera is a multipurpose fast-growing tree and is high in protein and vitamins (pro-vitamin $\mathrm{A}$, vitamins $\mathrm{B}$ and $\mathrm{C}$ ) and minerals $(\mathrm{Fe})$ and amino acids, methionine and cystine generally deficient in other feeds (Makkar and Becker 1996).

Leaves of the moringa tree are the preferred part for use in animal diets as leaf meal. Fresh leaves were found to contain $23 \%$ crude protein $(\mathrm{CP})$ in dry matter (DM), $12.3 \mathrm{ME} / \mathrm{kg}$ $\mathrm{DM}$ and had an in vitro DM digestibility of 79.7\% (Becker 1995). The CP of Moringa is of better bioavailability for ruminants because of its high content of bypass protein (Becker 1995).

\section{Materials and Methods}

The Moringa oleifera leaf meal sample used in the in vitro study was obtained from the department of Animal Nutrition GADVASU, Ludhiana and was air-dried and then ground in a Wiley mill through a $2 \mathrm{~mm}$ screen. The six concentrate mixtures were prepared by using various Moringa oleifera leaf meal (MOLM) levels replacing total crude protein of soybean meal at 10,20,30,40and 50\% i.e.
Concentrate 1(control), Concentrate 2(10\%MOLM), Concentrate 3 (20\%MOLM), Conc 4 (30\% MOLM), Concentrate 5 (40\% MOLM) and Concentrate 6(50\% MOLM) as shown in Table 1. All the concentrate mixtures prepared were iso-nitrogenous having approximately $20 \% \mathrm{CP}$. The samples were analyzed for proximate (AOAC, 2005) and cell wall components (Robertson and Vansoest, 1981).

\section{Kinetics of gas production}

Air equilibrated feed samples $(200 \pm 10 \mathrm{mg})$ of RH, CS and mixed diets were incubated in $100 \mathrm{ml}$ calibrated glass syringes in triplicate according to Menke and Steingass,(1988) with $30 \mathrm{ml}$ mixed rumen suspension with three blank incubations and standards. Cumulative gas production was recorded at 2 , $4,6,8,10,12,16,20,24,30,36,48,60$ and $72 \mathrm{~h}$ of incubation. The rate and extent of gas production were calculated by non-linear regression using the model $\mathrm{Y}=\mathrm{D}\left(1-\mathrm{e}-\mathrm{k}^{*} \mathrm{t}\right)$ where, $\mathrm{Y}$ is gas volume $(\mathrm{ml})$ at time $\mathrm{t}, \mathrm{D}$ is potential gas production $(\mathrm{ml})$ and $\mathrm{k}$ is rate (per hour) at which gas is produced (Orskov model, 1979; Krishnamoorthy et al., 1995). The time at half asymptotic gas production (t1/2) was calculated as $\ln 2 / \mathrm{k}$.

\section{Animal feeding and rumen analysis}

Rumen liquor was collected in morning (6 am) from the goats before feeding and watering into a pre-warmed thermo-flask and brought to the laboratory. The in vitro gas production was done according to Menke et al., (1979). The amount of net gas produced (NGP) was used to calculate the metabolizable energy (ME) value. Neutral Detergent Fibre (NDF) of the residue was also determined. Total degradable sample (TDS), organic matter degradability (\% OMD), partition factor (PF), neutral detergent fiber degradability (\% NDFD), microbial mass 
production (mg, MMP), efficiency of microbial mass production (\% EMMP), true digestibility (\% TD) and short chain fatty acids (mmol, SCFA) were calculated according to Makkar (2004). Volatile fatty acids (VFAs) were estimated by (Cottoyn and Boucque, 1968) using gas liquid chromatography (GLC) technique using Net Chrom-9100 model. The gas column (6 ft length and $1 / 8$ inch diameter) packed with chromosorb 101 was used for the estimation of VFA. The gas flow for nitrogen hydrogen and zero air were 30, 30, and $320 \mu \mathrm{l} / \mathrm{min}$, respectively. Temperature of injector oven, column oven and detector were $270^{\circ} \mathrm{C}, 172^{\circ} \mathrm{C}$ respectively.

\section{Statistical analysis}

Data found from in vitro study were analyzed 1x3 factorial design (Snedecor and Cochran, 1994), by using SPSS Version 19. The differences in means were tested by Tukey B.

\section{Results and Discussion}

\section{Ingredient and chemical composition of concentrates fed to male goats}

The ingredient and chemical composition of different concentrates supplemented with varying levels of moringa leaf meal is given in (Table 1 and 2). The CP content of control concentrate and moringa supplemented concentrate varied from $20.10 \%$ to $20.93 \%$. All the concentrate rations prepared were isonitrogenous in nature. The NDF content varied from $40.50 \%$ to $42.6 \%$. The fat content of ration was between $3.88 \%$ and 4.3 $\%$. The ash content in control concentrate ration was $7.57 \%$ while in moringa supplemented concentrates ration it varied from 7.10 to $7.40 \%$ and OM varied from $92.5 \%$ to $92.8 \%$ in moringa supplemented concentrate ration and in control concentrate it was $92.40 \%$. The total carbohydrates (TCHO) in control concentrate ration was
$66.23 \%$ while in moringa concentrate mixtures it varied from 56.30 to $62.63 \%$. The non-fibre carbohydrates (NFC) of the moringa supplement concentrates varied from $14.25 \%$ to 21.43 and in control, it was $26.63 \%$.

\section{In-vitro gas production data on in vitro utilization of nutrients of concentrates}

Concentrate mixtures containing different levels of replacement of $\mathrm{CP}$ of soybean with Moringa oleifera leaf meal is shown in Table 3. The control concentrate mixture has significantly produced lower $(\mathrm{p}<0.05)$ net gas production $(75.25 \mathrm{ml})$ and highest in $30 \%$ moringa based concentrate mixture $(88.0 \mathrm{ml})$. However, the $40 \%$ moringa concentrate produced net gas production $(84.50 \mathrm{ml})$ and in $50 \%$ moringa concentrate it was $(81.0 \mathrm{ml})$. There was no significant effect seen on a truly degraded substrate (TDS). It was statistically comparable in control, $40 \%$ and $50 \%$ moringa based concentrates mixtures. The partitioning factor $(\mathrm{PF})$ is the ratio of organic matter degraded (mg) in vitro to the volume of gas (ml) produced. A higher partitioning factor means that proportionally more of the degraded matter is incorporated into microbial mass i.e. the efficiency of microbial protein synthesis is higher. The partition factor calculated in vitro provides useful information for predicting the dry matter intake, microbial mass production in the rumen and the methane emission of the whole ruminant animal. The partition factor was significantly higher in Conc 2 (4.26) and Conc 3 (4.20) however, it was significantly lower in $30 \%$ moringa concentrate mixture (3.71). The Organic matter digestibility was statistically higher in $30 \%$ moringa based concentrate mixture $(93.26 \%)$ and significantly lowest in the control group (87.16\%). However, it was statistically comparable in all moringa containing concentrate mixtures as it varied from $89.00 \%$ to $92.13 \%$. A significant difference has been seen on neutral detergent fibre digestibility (NDFD\%) in all 
concentrates rations. It varied from $73.79 \%$ (30\% moringa concentrate mixture) to $57.91 \%$ (control concentrate mixture). The efficiency of microbial mass production was significantly higher $(\mathrm{p}<0.05)$ in $10 \%$ moringa based $(48.33 \%)$ concentrates and lowest in 30 $\%$ moringa rations $(40.71 \%)$. However, it was statistically comparable in control and 50\% moringa leaf meal concentrate mixture. There were statistically significant higher difference in true or dry matter digestibility in control $(87.60 \%)$ and moringa containing concentrate mixture (93.20\%) The control concentrate ration has produced significantly lower $(\mathrm{p}<0.05)$ short-chain fatty acids $(1.62 \mathrm{mmole})$ and highest in $30 \%$ moringa based concentrate mixture ( $1.91 \mathrm{mmole})$. The control concentrate rations had significantly higher $(\mathrm{p}<0.05)$ ammonia concentration $\quad(41.66$ $\mathrm{mg} / \mathrm{dl}$ ) and lowest in $40 \%$ moringa based concentrate $(33.03 \mathrm{mg} / \mathrm{dl})$ however, it was statistically comparable in 10 and $30 \%$ moringa containing concentrate. Metabolizable energy (ME) was statistically comparable in 10, 20 and 50\% moringa based concentrate mixtures. The ME value was significantly higher in $30 \%$ moringa based concentrate mixture and was found significantly lower in control concentrate rations. The amount of fermentable methane $(0.1820 \mathrm{mmol})$ was lower $(\mathrm{p}<0.05)$ in 10 and $20 \%$ moringa based rations and higher in 30 $\%$ moringa $(0.507 \mathrm{mmol})$ based rations, whereas fermentable carbon dioxide was significantly higher $(\mathrm{p}<0.05)$ in $40 \%$ moringa ration $(0.207 \mathrm{mmol})$ and lowest in control rations (0.182 mmole) (Fig. 1).

\section{In vitro volatile fatty acids production $(\mathrm{mM} / \mathrm{dl})$ of different concentrates containing different levels of moringa leaf meal}

The effect of different concentrate mixtures containing varying levels of moringa leaf meal on total and individual volatile fatty acids in vitro is presented in (Table 4 and Fig.
2). The TVFA was significantly lowest $(\mathrm{p}<0.05)$ in 10 and $20 \%$ moringa based ration $(4.86 \mathrm{mM} / \mathrm{dl})$ and was significantly higher in $30 \%$ moringa based concentrate mixture $(7.10$ $\mathrm{mM} / \mathrm{dl})$. The relative percent of acetate was significantly lowest $(49.15 \%)$ in $10 \%$ moringa supplemented concentrate mixture and highest in 30\% moringa based concentrate ration $(58.62 \%)$ and $50 \%$ moringa concentrate mixture $(56.01 \%)$.

The propionate percent was statistically higher in $10 \%$ moringa concentrate $(41.16 \%)$ and lowest in $30 \%$ moringa based concentrate mixture (31.68\%). The percent isobutyric was significantly higher $(\mathrm{p}<0.05)$ in $20 \%$ moringa concentrate mixture $(2.2 \%)$ whereas it was significantly lower in $30 \%$ moringa concentrate $(1.53 \%)$. The butyrate percent was observed to be significantly highest in $40 \%$ moringa concentrate ration (6.17\%) followed by $50 \%$ moringa $(5.99 \%)$ and $30 \%$ moringa based concentrate ration $(5.61 \%)$ and lowest percent in control ration (4.19\%). The isovalerate percent was significantly higher in $40 \%$ moringa concentrate ration $(1.39 \%)$ and lowest in $20 \%$ moringa concentrate mixture $(0.69 \%)$. The acetate to propionate ratio was significantly lowest $\quad(\mathrm{p}<0.05) \quad$ in $20 \%$ moringa supplemented ration (1.20) and highest in $30 \%$ moringa supplemented concentrate ration (1.89).

\section{Digestion kinetics parameters in vitro gas production of concentrates}

Cumulative gas production profiles from the in vitro fermentation of concentrates are shown in Figure 3 and the estimated parameters are given in Table 5. The cumulative volume of gas production increased with increasing time of incubation. The gas produced after $72 \mathrm{~h}$ incubation ranged between 56.83 and $65.33 \mathrm{ml}$ per 0.200 $\mathrm{g}$ of dry matter. 
Table.1 Ingredient composition of different concentrate mixtures containing Moringa oleifera leaf meal

\begin{tabular}{|c|c|c|c|c|}
\hline Ingredients & Control & $\mathbf{3 0 \%}$ MOLM & $\mathbf{4 0 \%}$ MOLM & $\mathbf{5 0 \%}$ MOLM \\
\hline Maize & 35 & 35 & 35 & 35 \\
\hline Soybean meal & 28 & 19.6 & 16.84 & 14 \\
\hline MOLM & 0 & 14 & 18.66 & 23.33 \\
\hline Wheat bran & 17 & 12 & 11 & 11 \\
\hline Rice bran & 14.75 & 14.9 & 14 & 12.5 \\
\hline Mineral mix & 2 & 2 & 2 & 2 \\
\hline Salt & 1 & 1 & 1 & 1 \\
\hline Urea & 0 & 0.5 & 0.5 & 0.6 \\
\hline By-pass fat & 2.25 & 1 & 1 & 0.57 \\
\hline
\end{tabular}

Table.2 Chemical composition of concentrates fed to goats, \% DM basis

\begin{tabular}{|c|c|c|c|c|}
\hline Parameters & $\begin{array}{c}\text { CONC 1 } \\
(\text { control })\end{array}$ & $\begin{array}{c}\text { CONC 2 } \\
(\mathbf{3 0 \%})\end{array}$ & $\begin{array}{c}\text { CONC 3 } \\
(\mathbf{4 0 \%})\end{array}$ & $\begin{array}{c}\text { CONC 4 } \\
(\mathbf{5 0 \%})\end{array}$ \\
\hline $\mathbf{D M}$ & 91 & 90.5 & 92 & 90 \\
\hline $\mathbf{A s h}$ & 7.575 & 7.1 & 7.125 & 7.475 \\
\hline $\mathbf{O M}$ & 92.425 & 92.9 & 92.875 & 92.525 \\
\hline $\mathbf{C P}$ & 20.27 & 20.1 & 20.26 & 20.93 \\
\hline $\mathbf{N D F}$ & 42.6 & 42.4 & 42 & 40.5 \\
\hline $\mathbf{A D F}$ & 10.5 & 10.75 & 12.3 & 12.6 \\
\hline $\mathbf{H C}$ & 32.1 & 31.65 & 29.7 & 27.9 \\
\hline $\mathbf{A D L}$ & 2.25 & 3.1 & 3.55 & 3.35 \\
\hline $\mathbf{E E}$ & 3.88 & 4.03 & 4.5 & 4.3 \\
\hline Cellulose & 8.25 & 7.65 & 8.75 & 9.25 \\
\hline TCHO & 68.275 & 68.77 & 68.115 & 67.295 \\
\hline NFC & 25.675 & 26.37 & 26.115 & 26.795 \\
\hline
\end{tabular}


Table.3 Effect of different levels of Moringa oleifera leaf meal-based concentrate mixtures on in-vitro utilization of nutrients

\begin{tabular}{|c|c|c|c|c|c|c|c|}
\hline Parameters & $\begin{array}{c}\text { CONC } \\
1\end{array}$ & $\underset{2}{\text { CONC }}$ & $\begin{array}{c}\text { CONC } \\
\mathbf{3}\end{array}$ & $\begin{array}{c}\text { CONC } \\
4\end{array}$ & $\begin{array}{c}\text { CONC } \\
5\end{array}$ & $\begin{array}{c}\text { CONC } \\
6\end{array}$ & SEM \\
\hline NGP, ml & $75.25^{\mathrm{a}}$ & $72.75^{\mathrm{a}}$ & $76.00^{\mathrm{ab}}$ & $88.00^{d}$ & $84.50^{\text {cd }}$ & $81.00^{\mathrm{bc}}$ & 1.69 \\
\hline TDS, mg & 346.68 & 347.25 & 349.87 & 350.06 & 349.68 & 345.75 & 0.51 \\
\hline PF & $4.01^{\mathrm{ab}}$ & $4.26^{b}$ & $4.20^{\mathrm{b}}$ & $3.71^{\mathrm{a}}$ & $3.81^{\mathrm{ab}}$ & $3.87^{\mathrm{ab}}$ & 0.066 \\
\hline OMD, \% & $87.16^{\mathrm{a}}$ & $89.20^{\mathrm{ab}}$ & $91.42^{\mathrm{bcd}}$ & $93.26^{\mathrm{d}}$ & $92.13^{\text {cd }}$ & $90.88^{\mathrm{bc}}$ & 0.63 \\
\hline NDFD, \% & $57.91^{\mathrm{a}}$ & $59.01^{\mathrm{a}}$ & $67.49^{\mathrm{ab}}$ & $73.79^{b}$ & $69.94^{b}$ & $70.68^{b}$ & 1.90 \\
\hline MMP, mg & $136.63^{\mathrm{a}}$ & $149.70^{b}$ & $152.67^{b}$ & $132.96^{\mathrm{a}}$ & $136.28^{\mathrm{a}}$ & $136.05^{\mathrm{a}}$ & 2.53 \\
\hline EMMP, mg & $45.21^{\mathrm{abc}}$ & $48.33^{c}$ & $47.72^{\mathrm{bc}}$ & $40.71^{\mathrm{a}}$ & $42.28^{\mathrm{ab}}$ & $43.29^{\mathrm{abc}}$ & 0.89 \\
\hline TD, \% & $87.60^{\mathrm{a}}$ & $89.73^{b}$ & $91.60^{\text {bcd }}$ & $93.20^{\mathrm{d}}$ & $92.13^{\text {cd }}$ & $91.06^{\mathrm{bc}}$ & 0.57 \\
\hline SCFA, mmol & $1.62^{\mathrm{a}}$ & $1.57^{\mathrm{a}}$ & $1.64^{\mathrm{ab}}$ & $1.91^{\mathrm{d}}$ & $1.83^{\text {cd }}$ & $1.75^{\mathrm{bc}}$ & 0.037 \\
\hline ME, MJ/Kg DM & $9.58^{\mathrm{a}}$ & $10.05^{b}$ & $10.13^{b}$ & $10.78^{d}$ & $10.49^{c}$ & $10.16^{\mathrm{b}}$ & 0.11 \\
\hline $\mathrm{NH}_{3}-\mathrm{N}, \mathrm{mg} / \mathrm{dl}$ & $41.66^{c}$ & $36.90^{b}$ & $32.14^{\mathrm{a}}$ & $35.12^{\mathrm{ab}}$ & $33.03^{\mathrm{a}}$ & $32.14^{\mathrm{a}}$ & 0.001 \\
\hline Ferm. $\mathrm{CO}_{2}, \mathrm{mmol}$ & $0.1820^{\mathrm{a}}$ & $0.1895^{\mathrm{ab}}$ & $0.1891^{\mathrm{ab}}$ & $0.1914^{b}$ & $0.2077^{\mathrm{c}}$ & $0.2036^{c}$ & 0.027 \\
\hline Ferm. $\mathrm{CH}_{4}, \mathrm{mmol}$ & $0.416^{\mathrm{b}}$ & $0.388^{\mathrm{a}}$ & $0.389^{\mathrm{a}}$ & $0.507^{d}$ & $0.470^{c}$ & $0.476^{\mathrm{c}}$ & 0.013 \\
\hline
\end{tabular}

Means bearing different superscripts in a row differ significantly $(\mathrm{P}<0.05)$

Table.4 In vitro volatile fatty acids production $(\mathrm{mM} / \mathrm{dl})$ of different concentrates containing different levels of MOLM

\begin{tabular}{|l|l|l|l|l|l|l|l|}
\hline Parameters & CONC 1 & CONC 2 & CONC 3 & CONC 4 & CONC 5 & CONC 6 & SEM \\
\hline Acetic acid & $3.284^{\mathrm{b}}$ & $2.390^{\mathrm{a}}$ & $2.397^{\mathrm{a}}$ & $4.167^{\mathrm{d}}$ & $3.627^{\mathrm{c}}$ & $3.100^{\mathrm{b}}$ & 0.193 \\
\hline Propionic acid & $2.501^{\mathrm{d}}$ & $2.002^{\mathrm{ab}}$ & $1.994^{\mathrm{ab}}$ & $2.251^{\mathrm{c}}$ & $2.203^{\mathrm{bc}}$ & $1.857^{\mathrm{a}}$ & 0.066 \\
\hline Iso butyric acid & $0.117^{\mathrm{b}}$ & $0.101^{\mathrm{ab}}$ & $0.107^{\mathrm{b}}$ & $0.108^{\mathrm{b}}$ & $0.107^{\mathrm{b}}$ & $0.085^{\mathrm{a}}$ & 0.003 \\
\hline Butyric acid & $0.267^{\mathrm{b}}$ & $0.210^{\mathrm{a}}$ & $0.211^{\mathrm{a}}$ & $0.398^{\mathrm{d}}$ & $0.404^{\mathrm{d}}$ & $0.331^{\mathrm{c}}$ & 0.024 \\
\hline Iso valeric acid & $0.056^{\mathrm{bc}}$ & $0.026^{\mathrm{a}}$ & $0.033^{\mathrm{ab}}$ & $0.069^{\mathrm{cd}}$ & $0.091^{\mathrm{d}}$ & $0.070^{\mathrm{cd}}$ & 0.007 \\
\hline Valeric acid & $0.149^{\mathrm{c}}$ & $0.132^{\mathrm{d}}$ & $0.124^{\mathrm{cd}}$ & $0.111^{\mathrm{bc}}$ & $0.108^{\mathrm{b}}$ & $0.091^{\mathrm{a}}$ & 0.005 \\
\hline TVFA & $6.37^{\mathrm{c}}$ & $4.86^{\mathrm{a}}$ & $4.86^{\mathrm{a}}$ & $7.10^{\mathrm{d}}$ & $6.54^{\mathrm{c}}$ & $5.53^{\mathrm{b}}$ & 0.26 \\
\hline Relative proportion, \% & \multicolumn{1}{|c|}{} & & & & & \\
\hline Acetate & $51.477^{\mathrm{b}}$ & $49.153^{\mathrm{a}}$ & $49.237^{\mathrm{a}}$ & $58.621^{\mathrm{d}}$ & $55.439^{\mathrm{c}}$ & $56.017^{\mathrm{c}}$ & 1.08 \\
\hline Propionate & $39.231^{\mathrm{c}}$ & $41.160^{\mathrm{d}}$ & $40.967^{\mathrm{d}}$ & $31.680^{\mathrm{a}}$ & $33.677^{\mathrm{b}}$ & $33.516^{\mathrm{b}}$ & 1.16 \\
\hline Iso butyrate & $1.848^{\mathrm{ab}}$ & $2.078^{\mathrm{bc}}$ & $2.212^{\mathrm{c}}$ & $1.529^{\mathrm{a}}$ & $1.647^{\mathrm{a}}$ & $1.537^{\mathrm{a}}$ & 0.083 \\
\hline Butyrate & $4.199^{\mathrm{a}}$ & $4.334^{\mathrm{a}}$ & $4.336^{\mathrm{a}}$ & $5.610^{\mathrm{b}}$ & $6.177^{\mathrm{c}}$ & $5.991^{\mathrm{c}}$ & 0.253 \\
\hline Iso valerate & $0.896^{\mathrm{ab}}$ & $0.555^{\mathrm{a}}$ & $0.692^{\mathrm{a}}$ & $0.983^{\mathrm{acc}}$ & $1.399^{\mathrm{c}}$ & $1.278^{\mathrm{bc}}$ & 0.097 \\
\hline Valerate & $2.347^{\mathrm{b}}$ & $2.717^{\mathrm{c}}$ & $2.554^{\mathrm{bc}}$ & $1.574^{\mathrm{a}}$ & $1.658^{\mathrm{a}}$ & $1.658^{\mathrm{a}}$ & 0.143 \\
\hline A:P ratio & $1.31^{\mathrm{c}}$ & $1.19^{\mathrm{a}}$ & $1.20^{\mathrm{a}}$ & $1.85^{\mathrm{d}}$ & $1.64^{\mathrm{c}}$ & $1.67^{\mathrm{c}}$ & 0.77 \\
\hline
\end{tabular}

Means bearing different superscripts in a row differ significantly $(\mathrm{P}<0.05)$ 
Table.5 Effect of different levels of MOLM on fermentation kinetics of concentrates

\begin{tabular}{|c|c|c|c|c|c|c|c|}
\hline Parameters & $\underset{1}{\text { CONC }}$ & $\underset{2}{\text { CONC }}$ & $\begin{array}{c}\text { CONC } \\
3\end{array}$ & $\underset{4}{\text { CONC }}$ & $\begin{array}{c}\text { CONC } \\
5\end{array}$ & $\begin{array}{c}\text { CONC } \\
6\end{array}$ & SEM \\
\hline $2 \mathrm{~h}$ & $5.00^{\mathrm{a}}$ & $4.66^{\mathrm{a}}$ & $4.33^{\mathrm{a}}$ & $3.83^{\mathrm{a}}$ & $6.16^{\mathrm{b}}$ & $6.83^{\mathrm{b}}$ & 0.27 \\
\hline $4 h$ & $11.33^{b c}$ & $11.00^{\mathrm{ab}}$ & $10.16^{\mathrm{ab}}$ & $9.00^{\mathrm{a}}$ & $12.16^{b c}$ & $13.33^{\mathrm{b}}$ & 0.37 \\
\hline $6 h$ & $20.50^{\mathrm{b}}$ & $21.00^{\mathrm{b}}$ & $20.50^{\mathrm{b}}$ & $16.83^{\mathrm{a}}$ & $19.83^{b}$ & $20.66^{\mathrm{b}}$ & 0.40 \\
\hline $8 h$ & $26.83^{\mathrm{b}}$ & $27.83^{\mathrm{b}}$ & $28.50^{\mathrm{b}}$ & $24.00^{\mathrm{a}}$ & $27.06^{\mathrm{b}}$ & $28.00^{\mathrm{b}}$ & 0.42 \\
\hline $10 \mathrm{~b}$ & 2002 & 31.66 & 33.16 & 30.50 & 34.50 & 33.16 & 0.46 \\
\hline I. & $33.83^{\mathrm{a}}$ & $34.50^{\mathrm{ab}}$ & $36.50^{\mathrm{ab}}$ & $35.16^{\mathrm{ab}}$ & $39.16^{\mathrm{b}}$ & $37.16^{\mathrm{ab}}$ & 0.56 \\
\hline 2 & $46.83^{\mathrm{a}}$ & $47.16^{\mathrm{a}}$ & $49.83^{\mathrm{ab}}$ & $50.16^{\mathrm{ab}}$ & $54.50^{c}$ & $52.00^{b c}$ & 0.70 \\
\hline $36 \mathrm{~h}$ & $52.00^{\mathrm{a}}$ & $52.16^{\mathrm{a}}$ & $55.66^{\mathrm{ab}}$ & $55.50^{\mathrm{ab}}$ & $60.16^{c}$ & $57.50^{\mathrm{bc}}$ & 0.75 \\
\hline $48 h$ & $54.66^{\mathrm{a}}$ & $54.83^{\mathrm{a}}$ & $59.00^{\mathrm{abc}}$ & $57.83^{\mathrm{ab}}$ & $63.00^{c}$ & $60.00^{\mathrm{bc}}$ & 0.78 \\
\hline $60 \mathrm{~h}$ & $56.00^{\mathrm{a}}$ & $56.33^{\mathrm{a}}$ & $61.00^{b c}$ & $59.16^{\mathrm{ab}}$ & $64.83^{c}$ & $62.00^{b c}$ & 0.83 \\
\hline $79 \mathrm{~b}$ & $56.83^{\mathrm{a}}$ & $57.16^{\mathrm{a}}$ & $65.33^{\mathrm{b}}$ & $59.66^{\mathrm{ab}}$ & $65.50^{\mathrm{b}}$ & $62.66^{\mathrm{ab}}$ & 1.03 \\
\hline
\end{tabular}

Means bearing different superscripts in a row differ significantly $(\mathrm{P}<0.05)$

Table.6 Estimated parameters of concentrates containing varying levels of moringa leaf meal when incubated with rumen fluid at different incubation times

\begin{tabular}{|l|c|c|c|c|c|c|}
\hline Parameters & CONC 1 & CONC 2 & CONC 3 & CONC 4 & CONC 5 & CONC 6 \\
\hline Yo (a) & -4.457 & -5.471 & -5.782 & -7.984 & -5.656 & -3.33 \\
\hline Plateau (a+b) & 55.87 & 55.91 & 61.72 & 59.58 & 65.10 & 62.13 \\
\hline K (c) & 0.08526 & 0.08969 & 0.08056 & 0.08128 & 0.07956 & 0.07904 \\
\hline Tau (V min) & 11.73 & 11.15 & 12.41 & 12.3 & 12.57 & 12.65 \\
\hline Half life & 8.13 & 7.728 & 8.604 & 8.528 & 8.712 & 8.769 \\
\hline Span (b) & 60.33 & 61.38 & 67.50 & 67.57 & 70.76 & 65.45 \\
\hline R square & 0.995 & 0.9936 & 0.9856 & 0.9968 & 0.9856 & 0.99 \\
\hline Lag time & $0.6 \mathrm{hr}$ & $0.4 \mathrm{hr}$ & $0.5 \mathrm{hr}$ & $0.6 \mathrm{hr}$ & $0.5 \mathrm{hr}$ & $0.2 \mathrm{hr}$ \\
\hline
\end{tabular}

$\mathrm{c}=$ gas production rate, $\mathrm{a}=$ gas production $(\mathrm{ml})$ from quickly soluble fraction, $\mathrm{b}=$ gas production $(\mathrm{ml})$ from insoluble fraction, $(\mathrm{a}+\mathrm{b})=$ potential gas production 
Fig.1 Effect of different levels of Moringa oleifera leaf meal-based concentrate mixtures on invitro utilization of nutrients

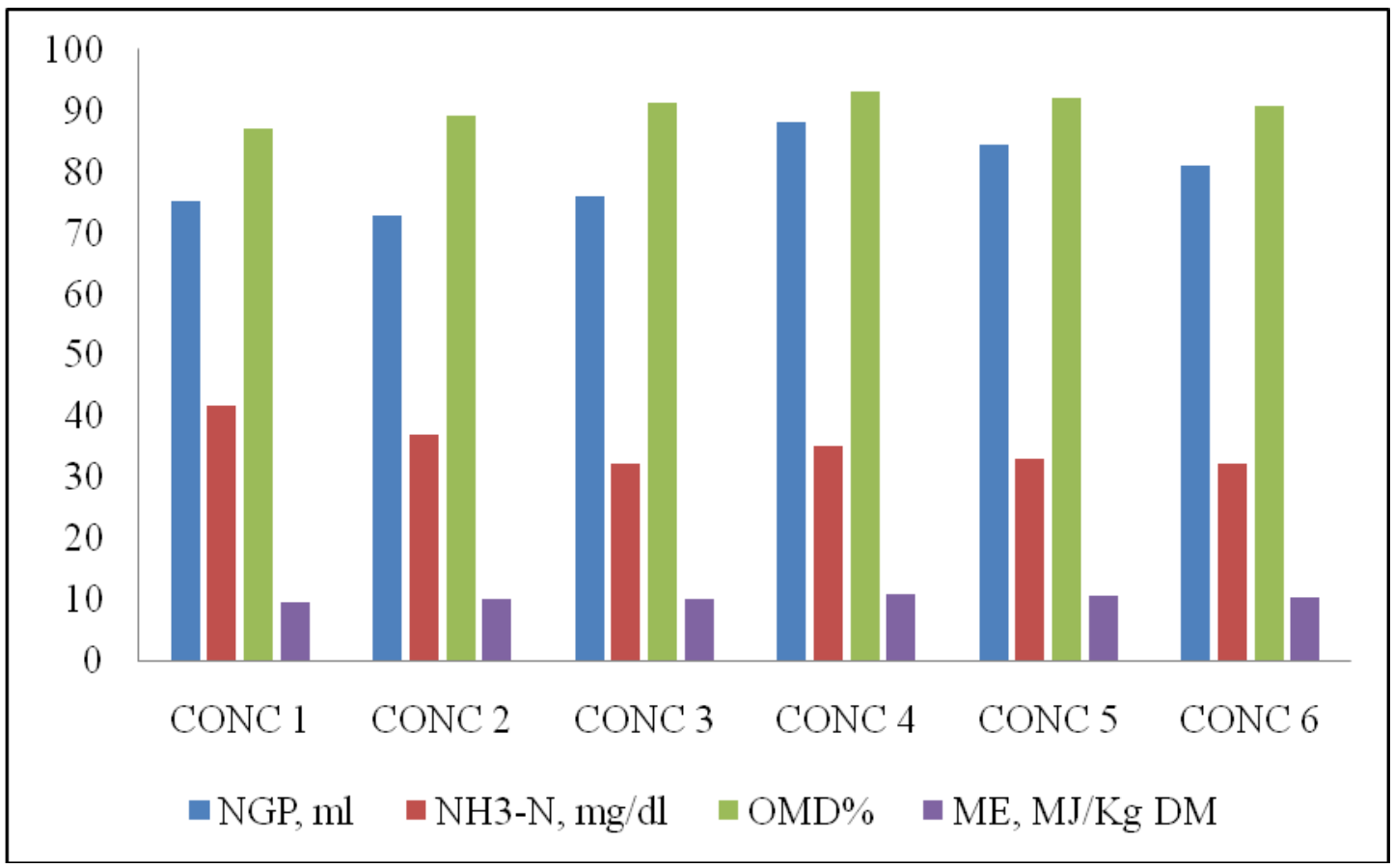

Fig.2 In vitro volatile fatty acids production $(\mathrm{mM} / \mathrm{dl})$ of concentrates containing different levels of MOLM

18

16
14
12
10
8
6
4
2
0

$\begin{array}{llllll}\text { CONC } 1 & \text { CONC } 2 & \text { CONC } 3 & \text { CONC } 4 & \text { CONC } 5 & \text { CONC } 6\end{array}$

Acetic acid Propionic acid Butyric acid TVFA A:P ratio 
Fig.3 Effect of different levels of MOLM on fermentation kinetics of concentrates

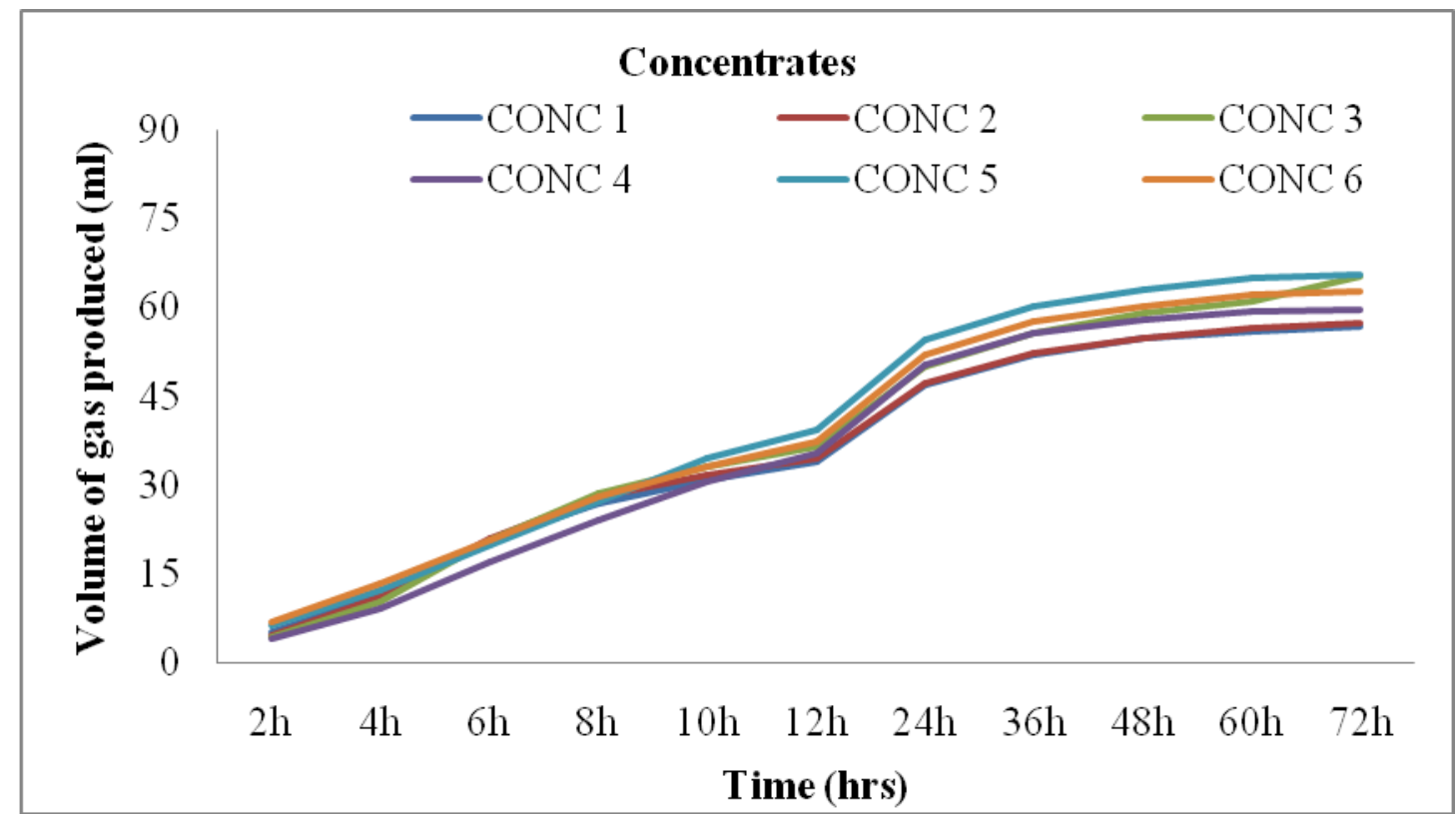

At $72 \mathrm{~h}$ incubation times, cumulative gas productions $(\mathrm{ml})$ of control and $10 \%$ moringa based concentrates have significantly $(\mathrm{P}<$ 0.05 ) lower than those of $30 \%$ moringa based concentrate. However, in all moringa based concentrates the cumulative gas production at $72 \mathrm{~h}$ is statistically comparable and on the higher side, as compared to control concentrate ration. The gas production in all the concentrates at $24 \mathrm{~h}$ has differed statistically non significantly (Fig. 3).

The gas production profiles presented in table 6 indicated that $\mathrm{Y}$ max (maximum potential of gas production) varied amongst the different concentrates evaluated. The Y max (ml) was lower in control TMR (55.87) and was higher in $40 \%$ moringa based concentrate $(65.10 \mathrm{ml})$ followed by $50 \%$ (62.13) and 20\% (61.72) moringa supplemented concentrates. However, the $\mathrm{V}$ min $(\mathrm{ml})$ ranged from 11.15 to $12.65 \mathrm{ml}$ in concentrates evaluated. It was lowest in $10 \%$ moringa supplemented concentrate (11.15) and highest in 50\% moringa supplemented concentrate (12.65). The maximum rate of degradation $(\mathrm{k})$ was observed in $10 \%$ moringa supplemented concentrate $(8.96 \%, \mathrm{~h})$ and lowest in $50 \%$ moringa concentrate $(7.90 \% \mathrm{~h})$. The value of 'a' was found lowest in 50\% moringa supplemented concentrate (3.33) and highest in 30\% moringa supplemented concentrate (7.98)

If ' $a$ ' is positive, then there is a component which is degraded rapidly and/or a component which is soluble. When a negative value for ' $a$ ' is obtained this means that there has to be an initiation period for degradation to start (termed the lag phase).

The $t \frac{1}{2}$ (time taken to reach half of the asymptote) was lowest for $10 \%$ moringa concentrate $(7.73 \mathrm{~h})$ and highest for $50 \%$ moringa concentrate $(8.76 \mathrm{~h})$. The value of "b" (gas production from insoluble fraction was lowest in control concentrate $(60.33 \mathrm{ml})$ and was highest in $40 \%$ moringa concentrate $(70.76 \mathrm{ml})$. In all the moringa based concentrates, the gas production from insoluble fraction was higher as compared to control concentrate (Table 5). The lag time 
was lowest in 50\% moringa concentrate (0.7hr) and was highest in 30\% moringa supplemented concentrate (1.5hr)

In conclusions, the net gas production was significantly increased as the moringa supplementation level increased in the concentrate ration. It was significantly higher in $30 \%$ moringa based concentrate and significantly lowest in control concentrate. The partition factor (PF) was significantly lowest in 30\% moringa concentrate (3.71) and significantly higher in $10 \%$ moringa containing concentrate mixture (4.26). The OMD was significantly higher in $30 \%$ moringa based ration and lowest in control ration but it was statistically comparable in moringa supplemented concentrate rations. The NDFD was significantly higher in $30 \%$ moringa concentrate ration but statistically comparable in moringa leaf meal supplemented concentrate rations. The MMP and EMMP was significantly higher in $10 \%$. However, it was statistically comparable in all moringa leaf meal supplemented concentrate rations. The true digestibility was significantly higher in $30 \%$ moringa supplemented and it was significantly lower in control ration. The ME value was significantly lower in control concentrate and statistically higher in $30 \%$ moringa supplemented ration followed by $40 \%$ moringa based ration. The $\mathrm{A}: \mathrm{P}$ ratio and TVFA was significantly lowest $(\mathrm{p}<0.05)$ in 10 and $20 \%$ moringa based ration $(4.86 \mathrm{mM} / \mathrm{dl})$ and was significantly higher in $30 \%$ moringa based concentrate mixture $(7.10 \mathrm{mM} / \mathrm{dl})$. At $72 \mathrm{~h}$ incubation times cumulative gas productions $(\mathrm{ml})$ of control was significantly $(\mathrm{p}<0.05)$ lower than that of $30 \%$ moringa based concentrate. The Y max ( $\mathrm{ml})$ was lower in control concentrate (55.87) and was higher in $40 \%$ moringa based concentrate $(65.10 \mathrm{ml})$ followed by $50 \%$ (62.13) and $20 \%$ (61.72) moringa supplemented concentrates. In all the moringa based concentrates the gas production from insoluble fraction (b) was significantly higher as compared to control concentrate. The lag time was lowest in $50 \%$ moringa concentrate $(0.2 \mathrm{hr})$ and was highest in control and 30\% moringa supplemented concentrate $(0.6 \mathrm{hr})$ It can be concluded that Moringa oleifera leaf meal can be replaced up to $30 \%$ of total crude protein of soybean meal without any adverse effect.

\section{References}

Association of official Analytical chemists (AOAC).2005. Official Methods for Analysis $17^{\text {th }}$ ed. AOAC International, Gaithersburg, MD.

Becker K. 1995. Studies on utilization of Moringa oleifera leaves as animal feed. Institute for Animal Production in the Tropics and Subtropics, vol. 480. University of Hohenheim, Stuttgart, p. 15 et seq Chemists, $17^{\text {th }} \mathrm{Edn}$, Washington D.C.

Cottyn B G and Boucque C V. 1968. Rapid methods for the gas chromatographic determination of volatile acids in rumen fluid. Journal of Agricultural Food Chemistry 16: 105-107.

Krishnamoorthy U, Soller H, Steingass H and Menke, K. H.1995. Energy and protein evaluation of tropical feedstuffs for whole tract and ruminal digestion by chemical analyses and rumen inoculum studies in vitro. Animal Feed Science and Technology 52(3-4): 177-88.

Makkar H P S and Becker K. 1996. Nutritional value and antinutritional components of whole and ethanol extracted Moringa oleifera leaves. Animal Feed Science and Technology 4: 211-28.

Menke K H, Raab L, Salewski A, Steingass H, Fritz D and Scheinder W. 1979. The estimation of the digestibility and metabolizable energy content of ruminant feed stuffs from the gas 
production when they are incubated with rumen liquor in vitro. Journal of Agriculture Science Cambridge 92: 217-222.

Menke K H, Raab L, Salewski A, Steingass H, Fritz D and Scheinder W. 1979. The estimation of the digestibility and metabolizable energy content of ruminant feed stuffs from the gas production when they are incubated with rumen liquor in vitro. Journal of Agriculture Science Cambridge 92: 217-22.
Orskov E.R., McDonald P.(1979): The estimation of protein degradability in the rumen from incubation measurements weighed according to rate of passage. J. Agric. Sci., 92, 499503

Robertson J A and P J Van Soest (1981). The Detergent system of analysis and its application to human food. In: The Analysis of dietary Fiber in Food (Ed W $\mathrm{P} \mathrm{T}$ James and $\mathrm{O}$ Theander). Marcel Dekker Inc., New York, pp. 123-158.

\section{How to cite this article:}

Pravin Sharma, J.S. Lamba, Jasmine Kaur and Grewal, R.S. 2020. In vitro Nutritional Evaluation and Digestion Kinetics of Concentrates Containing Varying Levels of Moringa oleifera Leaf Meal Supplementation as Protein Source for Goats. Int.J.Curr.Microbiol.App.Sci. 9(04): 3086-3096. doi: https://doi.org/10.20546/ijcmas.2020.904.360 